\title{
Humanizing Reading Comprehension Instruction: Using Reader Response Approach to Improve Al -Azhar First-Year Secondary School Students' Attitudes Towards Literature Reading
}

\author{
Mohamed Saad Mahmoud Hussein ${ }^{1}$, Abdullah Mahmoud Ismail², Muhammad Reyad Omar ${ }^{3}$ \\ ${ }^{2}$ Professor of Curricula \& EFL Methodology, Faculty of Education, Sohag University, Sohag, Egypt. \\ ${ }^{3}$ Lecturer of Curricula and instruction, Faculty of Education, Assiut University, Assiut, Egypt.
}

DOI:

\begin{abstract}
The aim of the study was to examine the effect of a suggested reader-response based program to teach literature on Al-Azhar first-year secondary school students' attitudes towards literature reading. The study participants consisted of 27 Al-Azhar first-year secondary school female students enrolled in AlQuseya Institute for Girls, Assuit governorate. The study employed a quasi-experimental one-group pretest-posttest design. The group chosen was initially assessed on literature reading attitude, received instruction in the Reader Response Based Program inspired by Rosenblatt's transactional theory, and was finally assessed again for their literature reading to gauge the difference between the initial and the second measurements. The data collected through the Literature Reading Attitude Scale were analyzed using the Wilcoxon Signed Rank test. Results showed progress in literature reading attitude either for the overall construct or the component subdomains. It is recommended that reading instruction be humanized through fusing the cognitive and affective aspects. More research is needed to study the potential horizons for the reader response in language teaching and learning. There is a need to enlarge the sample to enhance the generalizability of the results.
\end{abstract}

Key words: Reader response, literature reading attitude.

\section{Introduction}

Literature, as an instructional reading material, had been much neglected for a long time before it came back powerfully to the language classroom with the advent of the communicative approach in 1980s. Following this new sunrise of literature, the focus was no longer on literature as an end for learning, but as a means to language learning. Advocates of the resurrection of literature to the ELT context have their justifications.
Collie and Slater (2011) mention four reasons that invite teachers to use literature in the classroom; (a) It offers valuable authentic material that provides insights into fundamental human issues: (b) it provides a cultural enrichment that helps internalize understanding of how the people of the target language live (c) it helps enrich the linguistic aspects and make them more memorable (d) it promotes a personal involvement in the reading process. 
In the Egyptian EFL context, reading literature has received significant attention at least at the planning level as the Ministry of Education's National Curriculum Framework for English as a Foreign Language (2012)" encourages learners to read, respond and appreciate literature" (ElAraby et al., 2012, p. 9). The systematic exposure to literature reading, that spans third of the time assigned for English with two periods out of the total six lessons, is hoped to familiarize students with the extensive independent reading and enable them to engage in quality reading (Thompson 2017). Literary texts are suitable candidates as to address the characteristics inherent to secondary-age students since they help with crystalizing emotional identity and are influential in" developing awareness of the self as an Individual . . . increasing intellectual and emotional independence" (Pugliese \& Smith 2020, p. 4).

The emotional factors have been underlined by many scholars. Smith (1988, cited in McKenna \& Kear 1990) observed that the emotional interaction with the reading text "is the primary reason most readers read, and probably the primary reason most nonreaders do not read “(p.626). On the same wavelength, Huck (1973) sounded the alarmabout the underestimated position of attitudes in reading instruction and argued that" if we teach a child to read, yet develop not the taste for reading, all of our teaching is for naught. We shall have produced a nation of "illiterate literates" - those who know how to read, but do not read (p. 305). To put it another way, these practices might create schooltime readers, but they are unlikely to develop a life-time readers. The affective profile is an indispensable part in the reading process that we do not have the luxury of excluding them from the reading situation (Lukhele 2010).

The reading attitude, as an example of the emotional factors of learning, is defined by Mckenna et al. (2012) as "acquired predispositions to respond in a consistently favorable or unfavorable manner with respect to aspects of reading"(285). This binary inclination is formed due to numerous factors. Black (2006) suggests three sets of factors that cultivate the reading attitude; one is related to inner character traits, the second to the family and the third to school. School influences include, among other things, how teachers perceive their students and what content, strategies, and classroom discipline they choose and apply. The attitude towards reading is crucial in determining students' reading outcomes (Fakeye 2010; Stephens et al., 2015; Tahaineh \& Daana 2013). Abidin et al. (2012) contends that achievement in a target language relies not only on intellectual capacity, but also on the learner's attitudes towards language learning. This means that learning language should be approached primarily as a social and psychological phenomenon rather than as a purely academic one. The reader response approach seems to be a perfect candidate.

The reader response theory, suggested as a merger for intellect and affect, is a movement towards giving the reader an equal right or at the 
very extremist stance of the theory, an exclusive right in building the meaning (Hirvela 1996). Central to the theory is that each reader has a unique individual response derived from their unique schemata (Tracey 2017). Each reading encounter is unique given that it is unlikely that two readers reading the same text can have the same backgrounds, beliefs, and assumptions. Consequently, no two responses are expected to be alike. Rosenblatt (1995) contends that "There is no such thing as a generic reader or a generic literary work; there are only the potential millions of individual readers of the potential millions of individual literary works" (p.25). However, allowing for multiple responses doesn't mean tolerating any illogical response or supposing that responses are infinite. The responsible response, which the reader can support from the text, is the theory's replacement for the right-wrong response (Franzak 2008).

According to Rosenblatt (1995), text is a mere ink spot on a paper or a dead object. It is the reader who breathes life in this text through their reciprocal transaction with the text. During this transaction, both affective and cognitive dimensions of the reader are activated (Rosenblatt 1985). Rosenblatt posits that the interpretation of the text is a new text produced by the reader which she labels as a "poem". This means that when a reader responds to text in any form the starting point from which a response blossoms is not the text, but the meaning developed and the experiential state the text stirred up (Rosenblatt 1988).
Ali (1993) believes that the theory enhances creative and reflective thinking and makes the study of literature self-rewarding not just for acquiring language skills as is the case in most EFL contexts. Tucker (2000) argues that reader response qualifies the reading students as critics of the text who have the right to suggest their individual meaning of the text. Similarly, Ekstam (2018) states that the reader response provides framework for autonomous learning, fosters classroom discussions, and encourages students to express their opinions as well as listen to those of others.

Rosenblatt's transactional theory is the most successful attempt to take the reader response from the world of literary criticism to the pedagogical realm. For Rosenblatt, readers read for two purposes that travel through a continuum with two extremes; the efferent reading for factual information and the aesthetic purpose which refers to meaning made and the emotional states evoked out of the lived-through reading experience (Rosenallet 1985). The wide potential variety of the reader's aesthetic transaction with the text serves as a perfect pedagogical framework for applying the reader-response approach in the literary classroom (Cushing 2018). The key to aesthetic reading is the freedom of self-expression and the tolerance and even the invitation of different readings and collaborative share of opinions either while or after reading (Iskhak et al., 2017). It is a pre-requisite for the pedagogical application of the theory to provide room for students to express themselves in a 
democratically- driven threat-free environment that makes students personal associations accessible (Ishak 2016).

\section{Problem of the Study}

The traditional way of dictating the meaning and imposing specific authorities for interpretation has created passive readers perceiving no role of themselves in making meaning. As a result, they feel no relevance towards the text and reluctant to enter the text world and interact with it. This results in students who are deprived of "opportunities to develop critical thinking and distrustful of their own abilities to respond to literature in personal and important ways, most of them will not leave school with a love of reading" (French 1987, p.29).

The ultimate goal of teaching literature in the secondary stage is not to create literary critics but to provide what it takes to make a reader who personally approaches the text in a way that adds to them either intellectually or emotionally. Teachers should teach literature" so that the experience with literature is its own justification, so that the time spent talking and writing is compelling enough that it doesn't require formal defense?" (Probst 1994). However, the de facto teaching methodology common in the EFL context in Egypt in the secondary stage marginalizes the reading experience. Reading literary texts in our classrooms is reduced to just scanning summaries of the original texts with the purpose of answering some mainly literal questions. This in turn, creates a degree of alienation with the text being read.

From his capacity, as an EFL teacher working for Al-Azhar, the researcher of the current study noticed that when first-year secondary school students deal with the simplified literary story, they read the text word by word and feel so overwhelmed by the bountiful amount of new vocabulary that they either have the dictionary as their companion or keep asking their teachers about new words. This often results in their failure to have a big picture of the text or unveil the inferential meaning. For them, interpretations are perceived as the role of the teacher or their more competent colleagues. This way, they lose interest in and have a kind of apathy towards reading literature, finally limiting reading to informational meaning and depriving them of enjoyment of reading aesthetically. The researcher also noticed that students deal with the assigned literary works from a utilitarian perspective making them feel no fun or enjoyment in reading. This, in turn, brought about a negative attitude towards literature reading.

To establish the validity of these observations, the researcher has administered a literature reading attitude scale covering the different functions of reading to 32 students not included in the experimental group. Results of the attitude scale showed that students, on the whole, held a negative attitude towards reading English literature. The overall mean of the scale was 2.58 out of 5 which implies a negative reading attitude towards literature reading. As for the three 
subdomains of the scale, the enjoyment subdomain came last with a mean of 1.51 . The other two sub-domains were relatively better as the self-development accrued the highest mean of 2.84 followed by the utility with a mean of 2.64. Still, all the three domains are below the agree range as they fall under the neutral range of 2.60 3.39 except for the enjoyment subdomains whose mean came within the completely disagree range. Different reasons underlie the problem of the study. The negative attitudes towards literature reading forms mostly through the pedagogies adopted by teachers that tend to focus on the cognitive aspects and neglect the affective ones. Due to lack of engaging instruction, students become passive listeners as they expect teachers to be the active provider of input during the learning process (Awang et al., 2010). Greenwood (1988, as cited in Baba 2008) warns that "if students particularly lower language learners, practice the habit of parroting other people's ideas and views; they will grow into passive, uncritical and vulnerable students" (p.37). In their strenuous attempts to improve students' performance in reading comprehension, teachers become overwhelmed by improving students' skills to read forgetting to play on their will to read. Sacrificing will for the sake of skill, or in other words, overvaluing skill at the expense of enjoyment in the course of reading often results in long-lasting aversion to reading on the part of the students (Seitz 2010).

To address the negative attitudes towards literature reading held by first-year secondary school students, the study investigated the influence of changing the traditional instructional method to the more engaging expression-free method of reader response. It seems plausible to suppose that changing these instructional methods to a more favourable one may contribute to implanting a more positive attitude (Martinez et al., 2008). Davis et al. (1992) Assert that how literature is taught in the classroom is deemed as a determinant factor in shaping the attitude; students that were afforded to connect personally with the text and had freedom to express themselves demonstrated more positive attitudes, whereas the traditional activities of teaching and evaluation that are memorization-dominated tended to bring about negative attitudes.

\section{Method}

Research design: The study employed the quasiexperimental one-group pretest-posttest design with non-random convenience sampling, The group chosen was initially assessed on literature reading attitude, received instruction in the Reader Response Based Program, and then were assessed again for their literature reading attitudes to gauge the difference between the initial and the second measurements.

Participants: The study used the convenience sampling. Two groups of first-year secondary school female students attending the same class in Al-Quseya secondary institute for girls, for which the researcher worked, participated in the study. Out of the 47 female students comprising the classroom, 27 students were chosen as the main 
research group of the study who received instruction in the Reader Response -Based Program. Another group of 20 students were selected as a pilot group to whom the attitude scale and a sample unit of the program were administered to make sure of their validity and to decide on the internal validity of the attitude scale.

\section{Instructional Materials}

A suggested Reader-Response Based Program was designed by the researcher to improve the literature reading attitudes of the participants as they read the simplified version of Oliver Twist. The instructional program consists of a framework, a teacher's guide, and a student's activity book. The program is made up of twelve two-lesson units. Each unit covers one strategy. The strategies addressed in the program are organized into two categories; those that invoke one mental process like visualization or inference which can be termed as one-dimensional strategies and those broad-spectrum reading strategies that operate several mental processes i.e., sketch to stretch and hot seating which may be termed as multi-dimensional reading strategies. The first category consists of five strategies, namely making predictions, making inference, making connections, self-questioning, and visualizing. The second set encapsulates reader-response journal, sketch to stretch, graffiti board, conscience alley, hot seating, role play and writing-in-role.
Strategies are meant to help students produce the different types of response which good readers often use and to guide students into employing their schemata and emotional reservoir during their efforts to build the meaning.

\section{- Validity of the program}

The program including the Framework, Teacher's Guide and the Activity Book was given to a jury of EFL specialists and experts to judge its validity. They were asked to assess the program in terms of linguistic statement, appropriateness of the objectives for the participants, the relatedness of the content to the objectives, the relatedness of the teaching methods and activities to the objectives and the appropriateness of the evaluation techniques to the objectives. Remarks and recommendations of the jury members were taken into account and some changes were incorporated in the program

\section{- Piloting the Program}

Before proceeding with the formal implementation of the program, it was piloted on a 20-student group of female students attending the same class who were excluded from the main group of the study. One sample unit was randomly chosen and delivered to them in a separate class. The program piloting was meant to get feedback on the program concerning the duration of the session, suitability of the activities and the appropriateness of the program for the subjects. The students' feedback was encouraging concerning the different components of the lesson including the content, the activities and so on. 


\section{- Teaching the Program}

The study was carried out during the first term of the scholastic year 2019\2020. It lasted for about eight weeks. Immediately after the pretest administration in the first week, students received instruction in the program. Each unit consisted of two lessons which were merged and taught in one fifty-minute session with a total of 12 sessions in addition to an orientation session and three evaluation units, one after each of the two main parts of the program and one summative evaluation unit. All the units were covered throughout the program that lasted for eight weeks. It is worth noting here that initial or first reading of the content chapter was assigned as a homework task. The aim was to allow for more exposure to the text, give students chance to contemplate and produce reflective responses and save the class time to discussion and refining the responses.

\section{Assessment tools}

A pre-post five-point Likert scale was developed $(1=$ Strongly Disagree to $5=$ Strongly Agree $)$ to assess first-year secondary school students' attitudes towards literature reading. The scale is based mainly on three functions of reading used as parameters for measuring the reading attitude, namely enjoyment, self-development, and utility. The functions were suggested by (Greaney \& Neuman 1990; Lewis \& Teale 1980; Stockmans 1999).

To verify the psychometric features of the attitude scale, it was verified in terms of referee validity and internal consistency validity. The scale was reduced from 40 items to 30 items due to the referee validity. Another ten items were reduced due to the internal validity test. Two types of reliability tests were applied to the scale, namely Test-retest reliability and Alpha Cronbach reliability.

\section{The Internal Consistency Validity}

The internal consistency validity of the literature reading attitude scale was measured using Pearson Correlation Coefficient. Three levels of correlational analysis were employed to check the internal consistency of the scale: the correlation between the score of each item and the total score of the scale, the correlation between the items and their domains and the correlation between every domain with the total score of the scale. The correlation coefficient of the three levels is described respectively in Table 1 and Table 2.

Table (1) Items Correlation with the Total Test Score and the Domains

\begin{tabular}{|c|c|c|c|}
\hline Domains & $\begin{array}{l}\text { Item } \\
\text { no. }\end{array}$ & $\begin{array}{l}\text { Correlation with the } \\
\text { total test score }\end{array}$ & $\begin{array}{l}\text { Correlation with } \\
\text { domains }\end{array}$ \\
\hline \multirow{6}{*}{ 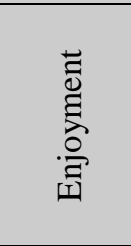 } & 1 & $.709^{* *}$ & $.788^{* *}$ \\
\hline & 2 & $.478^{*}$ & $.653^{* *}$ \\
\hline & 3 & $.513^{*}$ & $.530^{*}$ \\
\hline & 4 & $.487^{*}$ & $.608^{* *}$ \\
\hline & 5 & $.516^{*}$ & $.647^{* *}$ \\
\hline & 6 & $.676^{* *}$ & $.838^{* *}$ \\
\hline \multirow{8}{*}{ 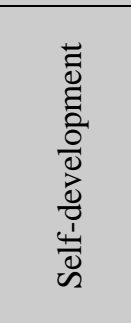 } & 7 & $.506^{*}$ & $.674^{\text {*** }}$ \\
\hline & 8 & $.663^{* *}$ & $.683^{* *}$ \\
\hline & 9 & $.623^{* *}$ & $.616^{\text {** }}$ \\
\hline & 10 & $.608^{* *}$ & $.688^{* *}$ \\
\hline & 11 & $.529^{*}$ & $.783^{* *}$ \\
\hline & 12 & $.532^{*}$ & $.624^{* *}$ \\
\hline & 13 & $.550^{*}$ & $.648^{* *}$ \\
\hline & 14 & $.585^{* *}$ & $.512^{*}$ \\
\hline \multirow{6}{*}{ 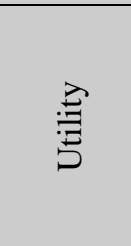 } & 15 & 459 & $.704^{* *}$ \\
\hline & 16 & $.453^{*}$ & $.539^{*}$ \\
\hline & 17 & $.501^{*}$ & $.804^{* *}$ \\
\hline & 18 & $.511^{*}$ & $.693^{* *}$ \\
\hline & 19 & $.534^{*}$ & $.786^{* *}$ \\
\hline & 20 & $.648^{* *}$ & $.750^{* *}$ \\
\hline
\end{tabular}

$\left(^{*}\right)$ the correlation coefficient is significant at (0.05) level.

(**) the correlation coefficient is significant at $(0.01)$ level. 
Table (2) Domains' Correlation with the Total Test Score

\begin{tabular}{ll}
\hline Domain & Correlation with total test score \\
& \\
\hline Enjoyment & $.829^{* *}$ \\
self-development & $.880^{* *}$ \\
Utility & $.722^{* *}$ \\
\hline (**) the correlation coefficient is significant at $(0.01)$
\end{tabular}

It is clear from Tables 1 and 2 that all correlation coefficients are significant at 0.05 or 0.01 levels. This implies that the scale has high Internal Consistency Validity.

\section{Reliability of the Scale}

A scale is deemed reliable when it yields relatively the same results when re-applied in a similar setting. Two methods were used to establish the reliability of the Literature Reading Attitude Scale: Test-retest reliability and Alpha Cronbach reliability.

To establish the test-retest reliability, the scale was administered to the pilot group twice with two-week interval. The two sets of data were gathered and the correlation between them was computed using Pearson's correlation coefficient. Results indicated that the scale has an acceptable test-retest reliability of 0.977 for the whole scale. The correlation coefficient between the domains varies between $(0.929,0.941,0.972)$ for enjoyment, self-development and Utility respectively. This indicates high reliability.

Using SPSS, alpha coefficient was calculated for the whole scale items and for each domain. The interpretation of the results was based on the guidelines proposed by Cohen et al. (2007). These are detailed in Table 3. Cronbach's alpha for the whole scale was 0. 878. As for the domains, the alpha for the enjoyment domain was
$.750, .808$ for self-development and .803 for utility. All the Alpha values were within the acceptable range of acceptability as proposed by Cohen et al. (2007).

Table (3) Alpha Coefficient Guidelines (Cohen et al., 2007)

\begin{tabular}{ll}
\hline Parameter & Decision \\
\hline$>0.90$ & very highly reliable \\
$0.80-0.90$ & highly reliable \\
$0.70-0.79$ & Reliable \\
$0.60-0.69$ & marginally minimally \\
$<0.60$ & reliable \\
\hline
\end{tabular}

The final scale encompassed 20 items with five items worded negatively. The items were distributed across three domains: six for the enjoyment domain, eight for the self-development domain and six for the utility domain. For more details about the scale domains and the items making up each domain (see the appendix).

\section{Procedures}

The procedures of the current study were carried out in Al-Quseya Secondary Institute for girls in Assuit during the first term of the scholastic year 2019/2020. Following verification of psychometric properties of the Literature Reading Attitude Scale, it was administered to the study group. Then, the group was taught using the Reader Response Based Program for eight weeks. By the end of the program delivery, the scale was distributed to the group again. Data were collected and analyzed using the Wilcoxon Signed Rank test.

\section{Results of the study}

The Wilcoxon Signed Ranks test was used to explore the effect of the program on the students' 
literature reading attitude sacross two levels: the the effect on each of the three domains making up effect on the overall literature reading attitude and the scale.

Table (4) Wilcoxon Test Results and the Effect Size for the Differences Between the Pre and Post Applications of the Literature Reading Attitude for the Overall Scale

\begin{tabular}{|c|c|c|c|c|c|c|c|c|c|c|}
\hline \multirow{2}{*}{ Data source } & \multirow{2}{*}{ Test } & \multirow{2}{*}{ M } & \multirow{2}{*}{ SD } & \multicolumn{4}{|c|}{ Ranks } & \multicolumn{2}{|c|}{$\begin{array}{l}\text { Wilcoxon Sined- } \\
\text { Rank Test }\end{array}$} & \multirow[t]{2}{*}{$\begin{array}{c}\text { Effect } \\
\text { size }\end{array}$} \\
\hline & & & & Pre-post Test & $\mathbf{N}$ & $\begin{array}{l}\text { Mean } \\
\text { Rank }\end{array}$ & $\begin{array}{l}\text { Sum of } \\
\text { Ranks }\end{array}$ & $\mathbf{Z}$ & $\mathbf{P}$ & \\
\hline \multirow{3}{*}{$\begin{array}{c}\text { The overall } \\
\text { scale }\end{array}$} & Pre & 6110 & 1420 & Negative & 0 & .00 & .00 & & & \multirow[t]{3}{*}{0.62} \\
\hline & Pre & & & Positive & 27 & 14.00 & 378.00 & 4.55 & .000 & \\
\hline & Post & 75.15 & 10.29 & Tiers & 0 & & & & & \\
\hline
\end{tabular}

The results indicate that the program was effective in improving first-year secondary school students' overall literature reading attitude; there is a statistically significant difference at $(\mathrm{a}<0.05)$ in the students' estimation of the literature Reading between the first and second applications for the overall literature reading scale in favour of the second application. The z-value is 4.55 with a $\mathrm{p}$-value of .000 . The effect size value $(r)$ is 0.62 which means that the program has a large effect on improving the overall literature reading attitude.

With regard to the scale domains, the Wilcoxon Signed Rank test was used to determine the statistical significance of the difference in the mean scores between the pre-and postadministrations of the scale. Results are portrayed in Table 2.

Table (5) Wilcoxon Test Results and the Effect Size for the Differences Between the Pre and Post Applications of the Literature Reading Attitude for the Three Domains of the scale

\begin{tabular}{|c|c|c|c|c|c|c|c|c|c|c|}
\hline \multirow[t]{2}{*}{ Domain } & \multirow[b]{2}{*}{ Test } & \multirow[b]{2}{*}{$\mathbf{M}$} & \multicolumn{3}{|c|}{ Ranks } & & & \multicolumn{2}{|c|}{$\begin{array}{l}\text { Wilcoxon } \\
\text { Sined-Rank } \\
\text { Test } \\
\end{array}$} & \multirow{2}{*}{$\begin{array}{c}\text { Effect } \\
\text { size }\end{array}$} \\
\hline & & & SD & $\begin{array}{l}\text { Pre-post } \\
\text { Test }\end{array}$ & $\mathbf{N}$ & $\begin{array}{l}\text { Mean } \\
\text { Rank }\end{array}$ & $\begin{array}{l}\text { Sum of } \\
\text { Ranks }\end{array}$ & $\mathbf{Z}$ & $\mathbf{P}$ & \\
\hline \multirow[t]{2}{*}{ Enjoyment } & Pre & 14.44 & 3.68 & Neg & $\begin{array}{l}0 \\
27\end{array}$ & $\begin{array}{l}.00 \\
1400\end{array}$ & $\begin{array}{l}.00 \\
37800\end{array}$ & \multirow[t]{2}{*}{4.56} & \multirow[t]{2}{*}{.000} & \multirow{2}{*}{0.62} \\
\hline & post & 20.81 & 3.25 & Tiers & 0 & & & & & \\
\hline \multirow[t]{2}{*}{ Self-development } & Pre & 24.78 & 6.97 & $\begin{array}{l}\text { Neg } \\
\text { Positive }\end{array}$ & $\begin{array}{l}0 \\
27\end{array}$ & $\begin{array}{l}.00 \\
14.00\end{array}$ & $\begin{array}{l}.00 \\
378.00\end{array}$ & \multirow[t]{2}{*}{4.56} & \multirow[t]{2}{*}{.000} & \multirow[t]{2}{*}{0.62} \\
\hline & post & 29.81 & 4.84 & Tiers & 0 & & & & & \\
\hline \multirow[t]{2}{*}{ Utility } & Pre & 21.96 & 5.44 & $\begin{array}{l}\text { Neg } \\
\text { Positive }\end{array}$ & $\begin{array}{l}1 \\
22\end{array}$ & $\begin{array}{l}2.50 \\
12.43\end{array}$ & $\begin{array}{l}2.50 \\
273.50\end{array}$ & \multirow[t]{2}{*}{4.15} & \multirow[t]{2}{*}{.000} & \multirow{2}{*}{0.56} \\
\hline & post & 24.52 & 4.34 & tiers & 4 & & & & & \\
\hline
\end{tabular}

The results show that the program was successful in developing students' literature reading attitudes in each domain of the scale namely enjoyment, self-development and utility. The z-values of the domains are 4.56, 4.56 and 4.15 respectively.

The $\mathrm{p}$-value for the three domains is .000 . The effect size values are 0.62 for enjoyment and 0.62 means that the program has large effect size for the three domains.

\section{Discussion}

Results of the current study revealed that students' estimation of the literature reading was higher in the post administration of the scale than 
in the pre administration either for the whole scale or the composite domains. These results are in line with previous research results (i.e., Alfauzan \& Hussain 2017; Baba 2008; Ismail 2007; Tseng 2010). This progress can be justified by the essential philosophy underlying the program. A distinctive contribution of the program lies in integrating the cognitive and the affective aspects of learning and therefore dealing wholly with the learning process and giving the affection its due role in learning as complementary to cognition. This integration afforded the program to instill in the student's confidence that they have the right to build the meaning without being criticized and consequently distracted by the ensuing anxiety.

The program's humanization of reading comprehension through the affect-intellect integration is likely to create enjoyment with reading. It is notable from the first administration of the attitude scale that the enjoyment domain was the function which students estimated lower than the other two functions; in the pre administration of the scale the mean score for enjoyment was 14.44 compared to 20.81 for selfdevelopment and 29.81 for utility. The highest difference between the two administrations was that of enjoyment which moved from 14.44 to 20.81. The emphasis of the program was on creating an atmosphere that enhances enjoyment. The program provided opportunities for students to engage in reading via personalizing the reading process especially through the artistic and performative activities which might be one reason the students performed higher in the second application of the scale.

Moreover, the enhanced literature reading attitude can be attributed to the reciprocal relation between reading achievement and reading attitude (Liu 2014). There is a kind of communication between reading ability and reading attitude which means that they feed each other, and they both affect reading achievement (Martinez et al., 2008). The sense of achievement, which students experienced due to their ability to explore areas previously untrodden by them, contributed to their positive attitudes towards literature reading. In sum, the program has altered the negative ideas that affect the feelings and consequently the intention to read. This is in keeping with the Mathewson's (2004) conceptualization of the attitude model.

A wide range of studies indicated that reader response and the like pedagogical approaches tend to have positive influences on reading attitude (i.e., Hagan 2013; Lockwood 2012). For example, results of the study of Davis $\boldsymbol{e t} \boldsymbol{a l}$. (1992) indicate that methods that provide for personal connection with the text and encourage students to express themselves tend to improve reading attitude. In the same vein, results of the study of Lim et al. (2015) assert that the reading attitude is influenced, among other things, by the strategies employed and the teacher's attitude to reading. Hagan (2013) concluded that reading attitude improved due to students' receiving instruction in reading using the balanced literacy, which shares reader response in having the 
potential to bring about engagement through the provision for authentic experience and the active role of students in the learning process. An example from the Arab region is the study of Fehaima (2017) from Algeria who found that reader response was significant in improving attitude to literature. Results of the study of Chou (2015) indicated that reading attitude improves due to using reader response pedagogy to respond to eBooks.

\section{Conclusion}

\section{Implications}

The concluding results of the study highlights the significance of transaction between the reader and the text to empower students and give them their due right in making the meaning in a freedom and independence oriented class atmosphere. This enhances enjoyment with the literary text and give readers a sense of confidence in their ability to produce meaning rather than passively receive it from others.

The study serves as a call of action to integrate cognitive aspects with emptional ones and provide for the tools that can effect such integration. The research findings also provides supporting evidence for schema theory tenets. That is why the study encourages tolerance of diversity of interpretations and responses to the text as per the unique schemata of each reader and as guided by the text clues. In addition, this study stresses that the overriding concern should be for students to engage with and have interest in reading: other goals often ensue naturally.
Ensuing from this is that aesthetic reading should be put highest in the literature reading priorities, a thing that ought to be translated into activities that encourage students to identify with the text. Relative to this is that the study serves as a guide as for how to enhance reading attiude through personalizing the reading experience and counteracting the effects of the current drastic fact-driven reading context.

Moreover, the study illuminates the significance of multiple strategies to be at hand for students to be able to meaningfully and resourcefully transact with the different challenges of the text. Moreover, the study underlines the benefits of using arts in teacing literature which should be given more consideration as a vehicle to boost depth and breadth of students' understanding and appreciation of literature. The pedagogical reader response provides a framework that represents what happen during the reading process. This makes the reader response a prospective predictor of the learner's engagement in reading and therefore increases the likelihood of enhancing attitude towards reading.

\section{Recommendations of the Study}

In light of the results of the study, some practical recommendations could be offered for EFL teachers and curriculm designers which they can make use of to improve the current EFL learning setting.

\section{For syllabus Designers}

- Integrating aesthetic oriented activities in the syllabus design to meet the ultiamte goal of teaching literature. 
- Utilizing the reader response approach pedagogically in the structuring of the curriculum through the integration of learnercentred activities in which the student is the main player in the process of building the meaning.

\section{For EFL Teachers}

More attention should be directed to enhancing students' engagement and participation as means to build meaning not just preaching or imposing previously decided meanings.

\section{Suggestions for Further Research}

- an investigation examining the impact of reader response on the students' level of participation and quality of discussion.

- an investigation examining the impact of reader response on the level of tolerance and the democratic education.

- an investigation examining the impact of reader response on the other affective factors like motivation, interest and engagement.

\section{References}

Abidin M. J. Z., Pour-Mohammadi M. \& Alzwari H., 2012. EFL students' attitudes towards learning English language: The case of Libyan secondary school students. Asian social science, 8(2): 119.

Alfauzan A. H. \& Hussain A. G., 2017. Attitude towards and Perception of Literature in EFL Setting: A Case Study on QU Male Undergraduate Students. English Language Teaching, 10(1): 1-17.

Ali S., 1993. The reader-response approach: An alternative for teaching literature in a second language. Journal of Reading, 37(4): 288-296.
Awang Z., Kasuma S. A. A. \& Akma S., 2010. A study on Secondary School Students' perceptions of their motivation and attitudes towards learning the English literature component. Retrieved from http://eprints.utm.my/10716/1/A_Study_On_Secon dary_School_Students.pdf

Baba W. K., 2008. An investigation into teachers' and students' attitudes towards literature and its use in ESL classrooms: A case study at a Matriculation Centre in Malaysia (Doctoral dissertation, University of Leicester).

Black A. M. L., 2006. Attitudes to reading: An investigation across the primary years. Master of Education (Research) Australian Catholic University McAuley Campus

Chou I., 2015. Engaging EFL students in E-books using reader-response theory. The Reading Matrix: An International Online Journal 15(2): 167-181.

Cohen L., Manion L. \& Morrison K., 2007. Research methods in education. routledge.

Collie J. \& Slater S., 2011. Literature in the language classroom: A resource book of ideas and activities. Cambridge [u.a.: Cambridge Univ. Press.

Cushing I., 2018. 'Suddenly, I am part of the poem' texts as worlds, reader-response and grammar in teaching poetry. English in Education, 52(1): 7-19.

Davis J. N., Gorell L. C., Kline R. R. \& Hsieh G., 1992. Readers and foreign languages: A survey of undergraduate attitudes toward the study of literature. The modern language journal, 76(3): 320-332. 
Ekstam J. M., 2018. Metacognition and Reader Response: the use of reading $\operatorname{logs}$ in the envisionment-building classroom. Acta Didactica Norge Vol. 12, Nr. 2. Art. 7. Pp.2-27.

El-Araby S., et al., 2012. The National Curriculum Framework for English as a Foreign Language (EFL) Grades 1-12. Cairo: Ministry of Education.

Fakeye D., 2010. Students' personal variables as correlates of academic achievement in English as a second language in Nigeria. Journal of Social Sciences, 22(3): 205-211.

Fehaima A., 2017. EFL Learners'Responses and Attitudes Towards Literary Texts: The Algerian Context. European Journal of Research in Social Sciences Vol, 5(3).

Franzak J., 2008. Language arts: Reading and literacy in adolescence and young adulthood. in Good, T. L. (Ed.). 21st century education: A reference handbook (Vol. 1). Sage.

French P. R., 1987. Reader-response theory: A practical application. The Journal of the Midwest Modern Language Association, 20(2): 28-40.

Greaney V. \& Neuman S. B., 1990. The functions of reading: A cross-cultural perspective. Reading Research Quarterly, 172-195.

Hagan E., 2013. Student reading attitudes in relation to the instructional approach (Doctoral dissertation, Northwest Missouri State University).

Hirvela A., 1996. Reader-response theory and ELT. ELT journal, 50(2): 127-134.

Huck C. S., 1973. Strategies for improving interests and appreciation in literature. In A. Beery,
T. C. Barrett, \& W. R. Powell (Eds.), Elementary reading instruction: Selected materials $\left(2^{\text {nd }}\right.$ ed.). Boston: Allyn and Bacon.

Iskhak I., 2016. The application of reader-response theory in enhancing student teachers' affective and linguistic growth: A classroom action research in EFL teacher education in Indonesia. The English Teacher, (2): 13.

Iskhak I., Saleh M., Sofwan A. \& Hartono R., 2017. Investigating the Effects of Reader Response Journals on the Quality of Teacher Trainees' Responses to Literary Works. Theory and Practice in Language Studies, 7(10): 831-840.

Ismail H. I. H., 2007. Arabs as ESL readers of American literature: Their attitudes, their responses, and the sources of their misinterpretations (Doctoral dissertation, University of Pittsburgh).

Kirby J. R., Ball A., Geier B. K., Parrila R. \& Wade-Woolley L., 2011. The development of reading interest and its relation to reading ability. Journal of Research in Reading, 34(3): 263-280.

Lewis R., \& Teale W. H., 1980. Another look at secondary school students' attitudes toward reading. Journal of Reading Behavior, 12(3): 187201.

Lim H. J., Bong M. \& Woo Y. K., 2015. Reading attitude as a mediator between contextual factors and reading behavior. Teachers College Record, 117(1): 1-36.

Liu Y., 2014. Motivation and Attitude: Two Important Non-Intelligence Factors to Arouse 
Students' Potentialities in Learning English. Creative Education, 5(14): 1249.

Lockwood M., 2012. Attitudes to reading in English primary schools. English in Education, 46(3): 228-246.

Lukhele B. B., 2010. Exploring relationships between reading attitudes, reading ability and academic performance among teachers' trainees in Swaziland (Doctoral dissertation)

Martinez R. S., Aricak O. T. \& Jewell J., 2008. Influence of reading attitude on reading achievement: A test of the temporal-interaction model. Psychology in the Schools, 45(10): 10101023.

McKenna M. C. \& Kear D. J., 1990. Measuring attitude toward reading: A new tool for teachers. The reading teacher, 43(9): 626-639.

McKenna M. C., Conradi K., Lawrence C., Jang B. G. \& Meyer J. P., 2012. Reading attitudes of middle school students: Results of a US survey. Reading research quarterly, 47(3): 283306.

Montano D. E. \& Kasprzyk D., 2015. Theory of reasoned action, theory of planned behavior, and the integrated behavioral model. Health behavior: Theory, research and practice.

Probst R. E., 1994. Reader-response theory and the English curriculum. The English Journal, 83(3): 37-44.

Pugliese T. \& Smith J., 2020. New Hello! Year 1: Teacher's Guide. Giza, Egypt: Longman.
Rosenblatt L., 1995. Literature as exploration $\left(5^{\text {th }}\right.$ ed.). New York, NY: Modern Language Association of America.

Rosenblatt L. M., 1985. Viewpoints: Transaction versus interaction: A terminological rescue operation. Research in the Teaching of English, 96-107.

Seitz L., 2010. Student Attitudes toward Reading: A Case Study. Journal of Inquiry and Action in Education, 3(2): 30-44

Stephens M., Erberber E., Tsokodayi Y., Kroeger T. \& Ferguson S., 2015. Is Reading Contagious? Examining Parents' and Children's Reading Attitudes and Behaviors. Policy.

Stokmans M. J. W., 1999. Reading attitude and its effect on leisure time reading. Poetics, 26, 245261.

Tahaineh Y. \& Daana H., 2013. Jordanian undergraduates' motivations and attitudes towards learning English in EFL context. International Review of Social Sciences and Humanities, 4(2): 159-180.

Thompson S., 2017. Introduction. In Baxter, A\& Kilbey, L. Hello English! English for Secondary schools! Year 1. Longman.

Tracey D. H. \& Morrow L. M., 2017. Lenses on reading: An introduction to theories and models. Guilford Publications.

Tseng F. P., 2010. Introducing literature to an EFL classroom: Teacher's presentations and students' perceptions. Journal of Language Teaching and Research, 1(1), 53-65. 
Tucker L. P., 2000. Liberating students through reader-response pedagogy in the Introductory
Literature Course. Teaching English in The TwoYear College, 28(2): 199. 